\title{
THE IMPACT OF THE CHILD SUPPORT GRANT ON PARTICI- PATION IN THE LABOUR MARKET IN RURAL EASTERN CAPE
}

\section{Pius Tanga, Priscilla Gutura}

\section{INTRODUCTION}

South Africa suffers from high and rising poverty levels and extreme inequality. The social security system (mainly social grants) is the government's chief initiative in tackling these problems. It aims to reduce poverty among groups not expected to participate fully in the labour market, thereby increasing investment in health, nutrition and education. The provision of social security has historically been seen as a core feature of the welfare system aimed at the prevention of poverty during the transition to a multiracial democracy in South Africa. Post-apartheid South Africa moved from residual and institutional models of welfare policy to developmental social welfare, focusing on needy people who have been excluded from mainstream welfare and social security systems. The focus of welfare was on moving people out of poverty, and not only on the construction of social security for prevention, social compensation and income distribution (Department of Social Development, 1997).

The child support grant (CSG) is South Africa's largest social cash transfer programme in terms of the number of beneficiaries, and one of the government's most successful social protection interventions. The child support grant refers to a grant paid to a primary caregiver of a child who satisfies the criteria in terms of Section 6 of the Social Assistance Act (No. 13 of 2004). It has a value of R280 per person per month (as of April 2012) and is given to a caregiver of a child on the basis that the caregiver has a very low income (below R2 500) or no income at all. A person cannot receive it for more than six children. The CSG has since been dramatically expanded with older age groups gradually included. As from 2010 all (income eligible) children born after 1996 started receiving the CSG until they reach the age of 18 years. Even the means test was relaxed in October 2008, as it was increased to ten times the value of the grant for single caregivers (and double that for married caregivers) so that the means test automatically keeps pace with inflation (Department of Social Development, 2009). Until that time the means test had been fixed at the same nominal level of R800 in urban areas and R1 100 in rural areas for ten years. In the most extreme example, this meant that the means test for a married caregiver in an urban area changed from an income ceiling of R800 per month to R4 600 (Statistics SA, 2009). Estimates based on survey data suggest that this change in the means test should have brought an additional 1.5 million children into the net (Leibbrandt, Woolard \& Woolard, 2007). Statistics indicate that by 31 December 2011 the number of children getting CSG numbered 10792762 , with a growth rate of 2.15\% annually (South African Social Security Agency, 2012).

The CSG may have many positive impacts. It may help to ensure food security, aid parents in buying school uniforms and paying school fees, and thus support enrolment and attendance, increase access to credit by raising an individual's creditworthiness, alleviate poverty in the household, raise women's bargaining power in the household, 
and possibly fund job searches and/or day care or crèche for the beneficiary, enabling the mother to work. According to Patel, Hochfeld, Moodley \& Mutwali (2012), the CSG enhances women's power and control over household decision making in financial matters, general household spending and in relation to child wellbeing. Women's increased capability to make decisions and to exercise freedom of choice about how the grant is spent enables them to generate valuable outcomes that are important to the quality of their lives and that of their children. The authors further argue that the CSG contributes directly to a sense of empowerment of female grant beneficiaries and that it has some positive social transformative effects.

Williams (2007) highlighted the point that the unconditional CSG in South Africa is also associated with an increase in the labour force participation of mothers. There are several channels through which social grants, particularly the CSG, might lead to improved labour market outcomes. On an international level this potential of cash transfers has been recognised by a variety of observers (Devereux \& Sabates-Wheeler, 2004; Ravallion, 2003; Samson, Una, Ndlebe, Quene, Van Niekerk, Gandhi, Harigaya \& Abrahams, 2004). The common factor in these theories is the idea that having, or being in a household that has, a steady income in the form of a grant may make it possible for poor individuals to make high-return investments that liquidity constraints would otherwise prohibit. Some, but not all, of these investments may be directed towards seeking remunerative employment.

In Brazil evidence suggests that its large-scale Bolsa Familia social transfers programme has had a major impact on women's labour market participation. The participation rate of beneficiary women is $16 \%$ greater than for women in similar non-participating households. The programme has also reduced by $8 \%$ the probability of employed women leaving their jobs (Veras, Ribas \& Osorio, 2007:13). The programme helps women in services such as pre-schools and day care for their children, otherwise easing the time burdens placed on women, therefore offering women more opportunity to seek and continue employment (Social Research Center, 2008). Argentina's Jefes y Jefas de Hogarpublic works programme has also increased the propensity of workers, particularly women, to participate in the labour force and to find a job in the formal sector (Devereux \& Solomon, 2006).

Improved labour market outcomes are not explicit goals of the CSG, but it is reasonable to expect some consequences as the grant often reaches working-age members. Patel et al. (2012:3) found out that in Doornkop only 12.5\% of CSG beneficiaries were employed. It can be noted that high unemployment among CSG beneficiaries is closely associated with high overall female unemployment nationally and the huge domestic and care responsibilities of women with young children. This article therefore examines the impact of the child support grant on participation by rural female beneficiaries in the labour market in Nkonkobe Municipality.

\section{Area of study}

The Eastern Cape is the province with the second highest number of grant beneficiaries (after KwaZulu-Natal) of all the provinces in South Africa, with a total number of 
2672968 beneficiaries (South African Social Security Agency, 2012). According to the South African Social Security Agency (2012), the CSG beneficiaries in the Eastern Cape total 1845320 . The province inherited a massive legacy of poverty and inequality when the first democratic government took power in 1994. Poverty in the Eastern Cape is both widespread and deep. With an estimated population of 6.74 million inhabitants in the province in 2010, the majority $(87.6 \%)$ are trapped in poverty (Makiwane \& ChimereDan, 2010). This study was conducted in Nkonkobe Municipality in the Eastern Cape Province of South Africa. Nkonkobe municipality is divided into four major areas for administrative purposes: Fort Beaufort, Alice, Middledrift and Balfour.

The Nkonkobe Municipality is situated in the Amathole District Municipality, bordering the Nxuba and Municipality to the west and the Amahlathi Municipality to the east. The municipality has a predominantly rural population and has a total of 21 wards. About $20 \%$ of the population reside in urban settlements, mostly in the towns of Alice and Fort Beaufort (Hule, 2010). The municipality prides itself on being home to three educational institutions: University of Fort Hare; Lovedale College and Healdtown College. It is a poverty-stricken area with a very low human development index. Poverty is identified as a major concern as the unemployment rate stands at $82 \%$, with $85 \%$ of the employed earning less than R1 500.00 per month and 15\% without any form of income (Integrated Development Plans, 2010). Industrial activity is mainly agribusiness: citrus, beef production and two small-scale agri-processing plants in Alice and Balfour. The commercial sector is on the decline with a number of national retail outlets having closed down; however, the region commands immense agriculture and tourism potential, which has yet to be exploited (Mziwonke, 2008).

According to the Integrated Development Plans (2010:13), Nkonkobe has high rates of unemployment $(82 \%)$, poverty $(71.43 \%)$ and a high dependency ratio of 2.56 . Hule (2010) argued that overall very high levels of unemployment prevail, with many households being sustained through remittances of income from a single wage earner and various small-scale enterprises. Of those employed, a large proportion is in the public sector, particularly education and health. This is reflected in the higher levels of income in the Alice area. He further argues that the dependency on income from the public sector is mainly a result of the productive base of local economy being narrow, based on commercial farming, forestry and to a lesser extent tourism, much of which is focused on the Fort Beaufort area. Hule (2010) further argued that, while revenue is generated in these areas, the allocation of land for large-scale commercial farming of forestry does not support broad-based employment generation and the incomes of the majority are very low, despite the commercial activity. In Nkonkobe municipality employment levels and incomes are lowest, while poverty levels are highest in the Seymour and Middledrift areas. These areas are composed of scattered villages which do not have a strong productive base, given the relatively poor land, nor the high levels of public sector employment. There are, however, a range of economic activities taking place which include small-scale vegetable and poultry production, and manufacturing enterprises which are owner-funded. Improvements in infrastructure may enhance the viability of these ventures. 


\section{Research methodology}

A quantitative research design was adopted for the study. The total number of social grant beneficiaries in the area according to SASSA (2011) numbered approximately 43743 with 24701 receiving the child support grant. Two hundred female beneficiaries of CSG were selected to participate in the study.vThis sample was selected through multi-stage sampling. Nkonkobe municipality is divided into four major areas for administrative purposes: Fort Beaufort, Alice, Middledrift and Balfour; they are respectively comprised of $6,7,1$ and 7 wards as seen in Table 1 . In a multi-stage sampling procedure the units of study are selected in a random manner, thus one ward from three of the four major areas with more than one ward was randomly selected. For representative purposes, the Middledrift lone ward was included in the study. The following were selected in the first stage for each area: Fort Beaufort - Ward 20; Alice Ward 6; Balfour - Ward 7; and Middledrift - Ward 16. At the second stage, in each ward that was selected approximately $5 \%$ of the households with recipients were selected as the focal units of the study. In Ward 20 there were 1520 households, 76 were selected; in Ward 6 there were 1200 and 60 households were selected; in Ward 7 there were 480 households and 24 were selected; in Ward 16 there were 800 and 40 were selected. The selected households were included in the sample only upon enquiry and confirmation that the households were receiving CSG. For the selection of the respondents from each household, only the female beneficiaries were included in the sample frame. However, other households were selected for replacement whenever a household without a female beneficiary was selected.

The main instrument of data collection was a semi-structured questionnaire. The questionnaire used had mixed question types: open-ended and closed-ended questions. Questionnaires were captured and analysed with the help of Statistical Package for the Social Sciences (SPSS). The analysis of quantitative data in this study followed a multifaceted approach. The approach was that of simple descriptive methods by explaining the trends and levels through tables. The focus of the analysis was to determine whether there is any association between the child support grant and labour market participation. This was followed by determining the degree of association between these two variables (if any) and finally checking if the values of one variable can be used to predict the values of the other.

\section{Findings and discussion}

The main objectives of the quantitative survey were to provide detailed biographical information on beneficiaries and on the drive of beneficiaries to seek employment .The results are presented according to the logic of the questionnaire. Table 1 shows the age of the respondents. 
TABLE 1

AGE OF RESPONDENTS

\begin{tabular}{|c|c|c|}
\hline Age & Frequency & Percentage \\
\hline $21-25$ years & 13 & 5 \\
\hline $26-35$ years & 79 & 40 \\
\hline $36-40$ years & 35 & 18 \\
\hline $41-54$ years & 42 & 22 \\
\hline $55+$ & 30 & 16 \\
\hline TOTAL & 200 & 100 \\
\hline
\end{tabular}

NB: Decimal points are rounded up to whole numbers

According Table 1, the group between the ages of 26 and 35 formed the largest component of the respondents in this study (40\%). This group is followed by respondents aged 41 to 54 years and thereafter those aged 36 to 40 years, who respectively made up $22 \%$ and $18 \%$. Furthermore, Table 1 reveals that the age group between 21 and 25 years constituted the least number (5\%) of beneficiaries after the 55 years and above age group (16\%).

The study revealed that $74.5 \%$ of the female respondents were black, while $25.5 \%$ were coloured. There were no white or Indian female respondents. Regarding the marital status of respondents, $36 \%$ were cohabitating, $34 \%$ were single, $16 \%$ divorced, $14 \%$ widowed and $9 \%$ married.

Respondents were asked about their educational qualifications and the results indicate that the majority of respondents $(52 \%)$ had some secondary education, followed by those who hold a matriculation certificate $(28 \%)$. Twelve per cent $(12 \%)$ of the respondents indicated that they had tertiary qualifications, while the least number of respondents had some primary education (8\%). Communities in Nkonkobe municipality have limited employment opportunities and, with beneficiaries possessing low educational qualifications, it is difficult for them to migrate to other cities in search of employment. Single parents with low levels of education face formidable constraints. Given resource constraints, the provision of adult basic education since 1994 has not reached a significant number of caregivers. Similarly, job placement services do not seem to have explicitly targeted caregivers.

The respondents were further asked about the number of people staying in their households. Most respondents stayed in households with 5-6 people (45\%), followed by 3-4 people $(31 \%)$. However, it was also revealed that $21 \%$ stayed in households with more than 6 people, while 4\% indicated that they stayed in households with between 1-2 people. The respondents in the study were further asked about their employment status. Eighty per cent $(80 \%)$ said that they were not employed, while $20 \%$ were employed. Those who indicated that they were not employed were asked if they were looking for a job. Fifty-one per cent (51\%) mentioned that they were looking for jobs, while the remaining $49 \%$ were not searching for a job at all. 
Table 2 shows the frequency and percentage of employment applications submitted by the $51 \%$ of respondents who indicated that they had sought employment in the past 12 months.

TABLE 2

APPLICATIONS FOR WORK SUBMITTED

\begin{tabular}{|c|c|c|}
\hline Number of applications & Frequency & Percentage \\
\hline $1-5$ & 29 & 35 \\
\hline $6-10$ & 37 & 45 \\
\hline $10+$ & 16 & 20 \\
\hline TOTAL & $\mathbf{8 2}$ & $\mathbf{1 0 0}$ \\
\hline
\end{tabular}

According to Table 2, 55\% of the respondents had submitted 6-10 applications for employment and $35 \%$ and $20 \%$ respectively submitted $1-5$ and 10 or more applications for employment. Searching for a job can be expensive, both in terms of expenditure such as transportation or telephone calls and the opportunity cost of not performing other remunerative or non-remunerative labour. Childcare can be another expense. Therefore, as Samson et al. (2004) maintain, social grants may play an important role in financing a job search. In their study of a sample drawn from the working class in Cape Town, Shoër and Leibbrandt (2006:22) report that the "most significant constraint on the ability of passive searchers to pursue (more active) search methods is the obligation to do domestic duties." Having a steady income in the form of a grant, or being in a household that does, may make seeking employment possible or improve its effectiveness. Alternatively, this income might permit beneficiaries to migrate in pursuit of employment, both by financing their move and by providing for children and other dependents who remain in the household of origin, as Posel, Fairburn and Lund (2004) aptly revealed.

A variant of the search-financing theory applies to holding a job. A grant may allow a single mother to place a young child in a crèche, or day-care centre, while she is at work. One possible confounding factor is that having access to a means of support may allow individuals to be more selective about accepting jobs. While this would appear to have a negative impact on employment, it may actually be economically beneficial; if individuals simply take the first job that comes along out of desperation, high productivity worker-firm matches may be precluded (Wittenberg, 2002). The role of social grants in reducing the cost of seeking employment may be especially important in households that have recently experienced negative shocks. In the context of the HIV/AIDS epidemic Booysen and Le Roux (2004:543) argue that social grants may "be important in mitigating certain aspects of the impact of the epidemic, for example, ensuring food security, making sure that children attend school and mitigating the burden of funeral costs, particularly in the case of households that have directly experienced illness or death and that are chronically poor." Having access to a stable income may help household members seek employment as a response to such crises. 
Table 3 illustrates the frequency and percentage of the reasons why all those respondents who were unemployed were not finding jobs.

TABLE 3

OBSTACLES IN FINDING JOBS

\begin{tabular}{|l|c|c|}
\hline \multicolumn{1}{|c|}{ Obstacles } & Frequency & Percentage \\
\hline No/few jobs available & 55 & 35 \\
\hline Not enough qualifications & 64 & 40 \\
\hline No relevant experience & 19 & 12 \\
\hline Other & 22 & 13 \\
\hline TOTAL & $\mathbf{1 6 0}$ & $\mathbf{1 0 0}$ \\
\hline
\end{tabular}

When asked about the greatest obstacles to finding jobs, 35\% cited "no/few jobs available". Although this is a demand-side factor that may require macroeconomic policy shifts, some of the other reasons cited suggest possible supply-side interventions. For example, $40 \%$ cited "not enough qualifications" and $12 \%$ gave "no relevant experience" while a further $13 \%$ cited other reasons.

Nevertheless, $49 \%$ of the unemployed beneficiaries indicated that they were not looking for a job. Economic theory suggests that people who receive regular free transfers will be discouraged from seeking work, especially if the value of the transfer is close to the income that the recipient could expect to earn from paid employment (Devereux \& Solomon, 2006). According to the South African Social Security Agency (2012), the CSG is R280/month for each child up to a maximum of six children. The incentive effects of social grants could operate both directly and indirectly. Directly, means-tested social grants disincentivise employment by requiring beneficiaries and their spouses to fall below a certain income threshold. In South Africa this effect would apply principally to the CSG, which imposes thresholds of R800 or R1 100 per month - low enough to disqualify wage earners above the 34th and 46th percentile of workers. Alternatively, the direct disincentive effect may result from a problem of intra-household allocation. If the members of the household share a grant, and the amount an individual successfully claims varies inversely with his/her own income, the incentive to work could be reduced (Bertrand et al., 2000).

Although most household-level studies of poverty consider household formation to be exogenous, in high-poverty situations individuals will tend to join households with more resources. According to the Department of Social Development (2006), in South Africa social grants represent a large proportion of the income for the poor, and since the old age grant $(\mathrm{OAG})$ and CSG beneficiaries are disproportionately concentrated in rural areas (as with the population of children and the elderly in general), this may lead to working-age individuals attaching themselves to rural households. This could occur either by migration to rural areas, or by rural youths delaying leaving home to set up their own households or to join relatives in urban areas. Since both unemployment rates and the cost of a job search tend to be higher in rural areas than in urban areas, using 
social grants to cope with poverty could pull workers away from jobs and indirectly discourage their job search (Klasen \& Woolard, 2005).

Social grants may also improve a worker's productivity and therefore make him/her a more attractive prospective employee (Samson et al., 2004). Workers who are malnourished or in poor health are likely to be less productive and so increasing their consumption can increase their employment prospects. Similarly, increased income may allow workers to invest in training and education, although it is possible that the grants would be used primarily to fund the education of children rather than adults. Hunger and health are also important constraints to a job search. Shoër and Leibbrandt (2006:20) reported that, in their sample, health problems hindered $13 \%$ of searchers, while hunger hindered $25 \%$. They were then asked whether the value of the social grant was sufficient to discourage them from seeking work, 32\% strongly disagreed, 58\% disagreed, $7 \%$ agreed and only $3 \%$ strongly agreed. All the respondents, whether unemployed or employed, were asked whether they preferred receiving social grants to going to work. Seventy-five per cent (75\%) said they would prefer going to work rather than receiving social grants, whilst $25 \%$ argued that receiving social grants was better than employment.

Alternatively, the steady income stream from the grant may be used to finance small enterprise creation. Table 4 indicates the type of investments that were made by beneficiaries.

\section{TABLE 4}

TYPE OF INVESTMENTS MADE BY BENEFICIARIES

\begin{tabular}{|l|c|c|}
\hline \multicolumn{1}{|c|}{ Type of investment } & Frequency & Percentage \\
\hline Professional practice & 4 & 2 \\
\hline Subsistence farming & 4 & 2 \\
\hline Garden project & 7 & 4 \\
\hline Poultry farming & 6 & 3 \\
\hline Savings scheme & 45 & 23 \\
\hline Pig farming & 9 & 5 \\
\hline No investment & 125 & 63 \\
\hline Total & $\mathbf{2 0 0}$ & $\mathbf{1 0 0}$ \\
\hline
\end{tabular}

Results according to Table 4 indicate that almost $63 \%$ of the respondents had not made any investments, while about $37 \%$ had invested the money from CSG in one kind of business venture or the other. The study revealed that from the about $37 \%$ who had made investments, it was those respondents who had been beneficiaries for quite some time. Some $23 \%$ of the respondents had invested in savings schemes, $5 \%$ in pig farming, $4 \%$ in garden projects and 3\% in poultry. Furthermore, Table 4 shows that the least number of respondents had invested in professional practice and subsistence farming ( $2 \%$ of the respondents in each case).

One interesting possibility is that the child support grant may act as an indirect wage subsidy by reducing the necessity of sending remittances and thereby encouraging even 
non-beneficiaries to work more. Remittances continue to play an important role in the South African economy, in part, because of the lack of government support for the unemployed, but it is the working poor and working class who bear the heaviest burden in providing for their even poorer friends, family and neighbours. This effectively creates a tax on income (Samson et al., 2004:22). However, there is strong evidence to suggest that when a household receives a social grant, there is a drop in the value of remittances it receives, meaning that the sender of the remittances gets to keep more of his/her money as a result (Jensen, 2004). This lowers the effective tax on labour and therefore encourages an increased labour supply. However, this theory is difficult to test with existing data because it requires information about both the household that sent the remittances and the household that received them.

\section{CONCLUSION AND IMPLICATIONS FOR SOCIAL WORK PRACTICE}

Evidence regarding the impact of cash transfers on the labour supply of beneficiaries and their household members is, however, mixed. Basic economic theory suggests that cash transfers are an injection of non-labour income into the households and, as such, should have an income effect on direct and indirect beneficiaries in the household. Thus, these transfers may well have the effect of reducing incentives for work. Bertrand, Miller and Mullainathans (2000) concluded that social grants had a negative effect on labour market participation. The results were attributed to the theoretical rationale, which postulates that as household income increases, the additional benefit to the household falls and thus work incentives are dampened (Samson, 2009). On the other hand, a cash transfer might assist in overcoming a liquidity constraint if migrant labourers initially need to draw resources from the original sending household. Samson and Williams's (2007) work using the Labour Force Survey supported this and concluded that there is a positive and significant impact on labour market participation and the probability of finding employment. Basically, evidence related to the labour supply effects of grants is quite mixed; grants seem to promote migration in search of employment, but also seem to provide some disincentives for working-age household members in looking for work.

It might be expected that those without jobs could have adapted to their circumstances and might hold opposing views of the importance of work. Female beneficiaries of the child support grant have the drive to search for employment, as they use the money for food in order to gain the strength to search for jobs, whilst also using the money for transportation in search of employment. By arguing that the money is not adequate for all their needs, they would thus prefer working to receiving the grant and this shows the determination to get a job. The child support grant enable workers to invest in a more productive job search by providing the critical support necessary for searching for decent work and not attaching themselves to the worst forms of labour out of desperation. Social grants therefore provide potential labour market participants with the resources and economic security necessary to invest in a high-risk/high-reward job search and receiving child social grant is correlated with a higher success rate in finding employment. 
The results demonstrate that South Africa's child support grant increases both the supply and demand for labour. This evidence does not support the hypothesis that South Africa's system of social grants affects employment creation negatively. The study conducted by Samson (2009) also supports the view that social protection services, if used for their intended purposes, can contribute to the reduction of gender inequalities in this case the CSG assisted women to access the labour market. This could be attributed to the possibility that the grant financed women's migration to look for a job and assisted older women to look after the children while their mothers were away. Jacobs et al. (2010) argue that, although the effect of the CSG seems small, the mere fact that the beneficiaries of the grant are more likely to participate in the labour force than non-beneficiaries is promising, as it somewhat dispels the earlier reservations about the potential impacts of social grants on labour force participation, namely that social grants create dependency.

Meeting basic needs is essential; however, some of the people interviewed felt that employment could make a significant difference for most people. It can be argued that human beings have the urge to be independent and useful. However, getting a grant every month and depending on it as the only source of income would not build communities, but if people are employed or skilled and still receive the grant, this will not only benefit the people themselves but the government as well. However, there are obstacles hindering beneficiaries from joining the labour market.

Social work practice can help ensure appropriate social protection responses to the differential risks and vulnerabilities faced by women. Gender needs to be mainstreamed into all aspects of policy and programme design for social protection, including targeting, linkages with complementary services, institutional arrangements, awarenessraising and monitoring and evaluation. Design options may include a range of responses according to the spectrum of protective, preventive, promotive and transformative programme objectives, as appropriate. This can be done through supporting women's organisations and awareness-raising efforts to increase women's participation in the labour market. Social workers should build institutional co-ordination between various stakeholders and ensure linkages and synergies with complementary sectors. Support should be given to effective gender analyses to improve understanding of the impact of changing risks and vulnerabilities (e.g. due to climate change and food price volatility) on women, and the implications for appropriate social protection responses over different timeframes. Strengthening the collection of gender-disaggregated data on poverty rates, programme coverage, income, nutritional status, access to health and education, employment conditions, and designing gender-specific programme actions will help redress inequalities that prevent women and girls from benefiting from or participating in the labour market.

\section{REFERENCES}

Bertrand, M., Miller, D. \& Mullainathan, S. 2000. Public Policy and Extended Families: evidence from South Africa. Working Paper No. 7594. South Africa: National Bureau of Economic Research. 
BOOYSEN, F. LE R. 2004. Income and poverty dynamics in HIV/AIDS affected households in the Free State Province of South Africa. South African Journal of Economics, 72(3):522-545.

DEPARTMENT OF SOCIAL DEVELOPMENT. 1997. White Paper for Social Welfare. Pretoria: Government Printers.

DEPARTMENT OF SOCIAL DEVELOPMENT. 2006. Linking social grants beneficiaries to poverty alleviation and economic activity. Discussion Document. Pretoria: DoSD.

DEPARTMENT OF SOCIAL DEVELOPMENT. 2009. Progress Report. [Online] Available: http://www.socdev.gov.za/Documents/2009/April/progr.PDF [Accessed: $12 / 02 / 2010]$.

DEVEREUX, S. \& SABATES-WHEELER, R. 2004. Transformative Social Protection Working Paper 232. Brighton: University of Sussex.

DEVEREUX, S. \& SOLOMON, C. 2006. Employment Creation Programmes: the international experience, issues in employment and poverty. Discussion Paper No. 24. Geneva: Economic and Labour Market Analysis Department, International Labour Office (ILO).

HULE, Z.C. 2010. An exploratory study of the impact of land redistribution on the rural poor: the case of Nkonkobe Municipality. Port Elizabeth: Nelson Mandela Metropolitan University. (MA thesis)

INTEGRATED DEVELOPMENT PLANS (IDP). 2010. Annual review. [Online] Available: http://www.buffalocity.gov.za/municipality/idp2010. (Accessed: 17/01/2012).

JACOBS, P.T., BAIPHETHI, M., NGCOBO, N. \& HART, T. 2010. Investigating the potential to promote local economic development and job creation through social grants expenditure. Centre for Poverty, Employment and Growth: Human Sciences Research Council.

JENSEN, R. 2004. Do private transfers 'displace' the benefits of public transfers? Evidence from South Africa. Journal of Public Economics, 88:89-112.

KLASEN, S. \& WOOLARD, I. 2005. Surviving unemployment without State support: unemployment and household formation in South Africa. Working Paper 129. Cape Town: Centre for Social Science Research, University of Cape Town.

LEIBBRANDT, M., WOOLARD, C. \& WOOLARD, I. 2007. Poverty and Inequality Dynamics in South Africa: Post-apartheid Developments in the Light of the LongRun Legacy. Cape Town: Southern Africa Labour \& Development Research Unit, University of Cape Town. [Online] Available: www.ipc-undp.org/ems/papers/.../ Leibbrandt_Woolard_Woolard_ENG.pdf [Accessed: 13/03/2011].

MAKIWANE, M.B. \& CHIMERE-DAN, D.O.B. 2010. The people matter: the state of the population in the Eastern Cape. East London: Research and Population Unit Eastern Cape Department of Social Development. 
MUllainathan, S. 2000. Public Policy and Extended Families: evidence from South Africa. Working Paper No. 7594. South Africa: National Bureau of Economic Research.

MZIWONKE, Q.L. 2008. The sustainability of poverty alleviation projects within the Nkonkobe Municipal Region. Pretoria: Cranfield College. (MA dissertation)

PATEL, L., HOCHFELD, T., MOODLEY, J. \& MUTWALI, R. 2012. The Gender Dynamics and Impact of the Child Support Grant in Doornkop, Soweto. CSDA Research Report. Johannesburg: Centre for Social Development in Africa, University of Johannesburg.

POSEL, D., FAIRBURN, J.A. \& LUND, F. 2004. Labour migration and households: a reconsideration of the effects of the social pension on labour supply in South Africa. Paper delivered at the African Econometrics Society Conference. Cape Town: 13-15 October.

RAVALLION, M. 2003. Targeted transfers in poor countries: revisiting the tradeoffs and policy options. Washington DC: World Bank. [Online] Available: http://www.chronic poverty.org/uploads/publication.../WP26_Ravallion.pdf. [Accessed: 14/03/2011].

SAMSON, M., UNA L., NDLEBE, A., QUENE, K.M., VAN NIEKERK, I., GANDHI, V., HARIGAYA, T. \& ABRAHAMS, C. 2004. The social and economic impact of South Africa's Social Security System. Economic Policy Research Institute. Commissioned by the Directorate: Finance and Economics for the Department of Social Development.

SAMSON, M. \& WILLIAMS, M. 2007. Social grants and labour market behaviour: evidence from South Africa's household surveys. Cape Town: Economic Policy Research Institute. (Research Paper, No.43.)

SAMSON, M. 2009. Social cash transfers and pro-poor growth, in promoting propoor growth: social protection. Paris: Organisation for Economic Co-operation and Development.

SOUTH AFRICAN SOCIAL SECURITY AGENCY. 2011. Annual statistical report on social grants. [Online] Available: www.sassa.gov.za. [Accessed: 06/05/2011].

SOUTH AFRICAN SOCIAL SECURITY AGENCY. 2012. Annual statistical report on social grants: 2010/11 report. South Africa, Pretoria. [Online] Available: www.sassa.gov.za. [Accessed: 06/04/2012].

SCHOËR, V. \& LEIBBRANDT, M. 2006. Determinants of job search strategies: evidence from the Khayelitsha/Mitchell's Plain Survey. Working Paper 167. Cape Town: Centre for Social Science Research, University of Cape Town.

SOCIAL RESEARCH CENTER. 2008. Introducing empowering conditional cash transfers to Egypt: the Ain el-Sira Experiment. America: University of Cairo. 
STATISTICS SOUTH AFRICA. 2009. General Household Survey 2009 Medata. South Africa, Cape Town. [Online] Available: www.statssa.gov.za/publications /P0318/P0318 June2009.pdf (Accessed: 14/03/2010).

VERAS, F., RIBAS, R. \& OSORIO, R. 2007. Evaluating the impact of Brazil's Bolsa Família: cash transfer programmes in comparative perspective. Evaluation Note 1, International Poverty Centre (IPC). Brasilia.

WILLIAMS, M.J. 2007. The social and economic impacts of South Africa's. BA dissertation, Williams College, Williamstown, MA thesis. [Online] Available: http:/ /www.williams.edu/Economics/Honors/2007/Williams thesis.pdf. [Accessed: 14/03/2011].

WITTENBERG, M. 2002. Job search in South Africa: a non-parametric analysis. South African Journal of Economics, 70(8):1163-1197.

Prof Pius Tangwe Tanga; Miss Priscilla Gutura, Department of Social Work/Social Development, University of Fort Hare, South Africa. 